\title{
Biotic and abiotic particles protect marine heterotrophic bacteria during UV and ozone disinfection
}

\author{
Ole-Kristian Hess-Erga ${ }^{1}$, Kari Johanne Kihle Attramadal ${ }^{2}$, Olav Vadstein ${ }^{1, *}$
}

${ }^{1}$ Department of Biotechnology, Norwegian University of Science and Technology, Sem Sælandsvei 6/8, 7491 Trondheim, Norway ${ }^{2}$ Department of Biology, Norwegian University of Science and Technology, Sealab, Brattørkaia 17B, 7010 Trondheim, Norway

\begin{abstract}
Disinfection of water is required for a range of applications, including ballast water treatment and land-based fish farming. Bacteria attached to or embedded in particles can be protected from the disinfectant by various mechanisms. We investigated inactivation of marine heterotrophic bacteria in the presence of biotic and abiotic particles. In one set of experiments with the planktonic rotifer Brachionus 'Nevada', water was exposed to increasing UV and ozone dose, and we examined inactivation of free-living and particle-associated heterotrophic bacteria. An estimated $99.9 \%$ inactivation of free-living bacteria was obtained compared to only $91.4 \%$ inactivation (3 of 4 experiments) of particle-associated bacteria at the same ozone dose. For the UV experiments, a 6 -fold increase in disinfection dose was required to obtain $99.9 \%$ inactivation of the particle-associated compared to the free-living bacteria. In a second set of experiments we investigated the protective effect of biotic (rotifers) and abiotic (ceramic clay) particles as a function of particle concentration. Increased particle concentration resulted in reduced disinfection efficiency of free-living bacteria with both UV and ozone. Rotifers protected slightly better against UV disinfection than ceramic clay particles, while such a relationship was not evident for the ozone disinfection. The results suggest a complex bacterial inactivation mechanism in the presence of particles, and will have implications for the treatment strategy used for ballast water and land-based fish farming.
\end{abstract}

KEY WORDS: Disinfection · Bacteria · Inactivation · Ozone · UV · Seawater · Biotic particles Abiotic particles

Resale or republication not permitted without written consent of the publisher

\section{INTRODUCTION}

Invasive species and pathogens can be introduced to natural ecosystems through sources like ballast water from ships and effluents from aquaculture. One way to reduce the transfer into new locations is to disinfect the water. UV irradiation and ozonation are 2 disinfection methods used in such situations; however, water used as ballast or in aquaculture can contain a wide range of type and concentration of particles which may interfere with the disinfection process.

Ozone $\left(\mathrm{O}_{3}\right)$ is a powerful oxidising agent and has been used as a treatment for the inactivation of organisms such as bacteria, in freshwater and seawater. By introducing ozone to seawater, a series of redox reac- tions take place and several reactive intermediates are formed. The main ozone demand in seawater is due to its reaction with bromide to form bromine compounds. The most important reaction in seawater during ozonation is the initial oxidation of bromide ions $\left(\mathrm{Br}^{-}\right)$to hypobromite ions $\left(\mathrm{OBr}^{-}\right)$which can then be reduced back to $\mathrm{Br}^{-}$or further oxidised to form bromate ions $\left(\mathrm{BrO}_{3}{ }^{-}\right)$(Buchan et al. 2005). The hypobromite ion will hydrolyse into hypobromous acid $(\mathrm{HOBr})$, which is a weak acid. The sum of $\mathrm{HOBr}$ and $\mathrm{OBr}^{-}$is the biocidal bromine. In seawater with a typical $\mathrm{pH}$ of 8 , hypobromous acid will predominate and be the most important disinfectant with a half-life of hours to days dependent on light conditions and water quality characteristics (Liltved et al. 2006). Dissolved ozone levels can be esti- 
mated indirectly by measuring the oxidation-reduction potential (ORP) or by the colorimetric $\mathrm{N}, \mathrm{N}$-diethylp-phenylenediamine (DPD) method. ORP may be used to control ozone addition to seawater but is not necessarily equivalent to the disinfective capacity of the water (Tango \& Gagnon 2003). Buchan et al. (2005) recommend the DPD 'total chlorine test' be used and express the results as total residual oxidant (TRO), in units of $\mathrm{mg} \mathrm{Cl}_{2} \mathrm{l}^{-1}$. The disinfection dose is commonly calculated from the average TRO concentration during the contact time and gives the $\mathrm{C} \cdot t$ value (i.e. the product of concentration and contact time).

The disinfective ability of UV irradiation is due to harmful changes in DNA molecules and mainly due to radiation in the UV-C spectral region. Light with wavelength around $254 \mathrm{~nm}$ will damage DNA and RNA by photo-induced dimerisation of adjacent pyrimidine in the nucleic acid strand. Due to covalently bound pyrimidine residues, replication of the nucleic acid is hindered or completely blocked. This effect can be temporal or lethal depending on the repair mechanisms and the degree of UV resistance. Many bacteria have developed mechanisms, some of which are dependent on light, with which to repair moderate damage. Photo reactivation is attributed to the ability of light in the wavelength range 330 to $480 \mathrm{~nm}$ to activate DNA photolyase. In the dark, excision repair has been shown to be the important mechanism. These recovery processes may be limited, but should not be neglected when assessing the efficiency of disinfection. Particular concern should be aimed at the processes that take place after discharge to the recipient water (Liltved \& Landfald 1996).

Bacteria adhered to or embedded in particles may obtain protection against chemical and non-chemical disinfection agents, with reduced disinfection efficiency as the result. This protection mechanism can act differently depending on the disinfection method used. The effect of disinfection by radiation such as UV can be reduced by particles shielding, absorbing, scattering and blocking of UV light from the bacteria. The effect of chemical disinfection agents can be reduced due to disinfectant degradation at the particle surface and rate-limited transport of disinfectants into the particle (Perrins et al. 2006a). Bacteria colonising the particle surface or inside, similar to the biofilm system, are known to be more resistant than free-living bacteria to chemical disinfection at lower concentrations of disinfectant (Wu et al. 2005). Many bacteria are known to be particle-associated and this could be a strategy to survive unfavourable conditions. The protective mechanisms will depend on particle properties such as size, type and concentration. To our knowledge the protective mechanisms of particles in seawater are poorly studied. We tested the following hypotheses: (1) parti- cles will protect embedded or attached bacteria from disinfectants; (2) disinfection efficiency of free-living bacteria is negatively correlated to particle concentration $_{i}(3)$ biotic particles give better protection of heterotrophic bacteria than abiotic particles; and (4) the properties of the disinfection methods cause UV disinfection to be more affected by particle concentration than ozone disinfection.

The present study was designed to give further insight into inactivation of heterotrophic bacteria in seawater and the protective effect of particles by ozone and UV. This was done by studying dose-inactivation relationships of free-living and biotic (rotifers) particleassociated bacteria, and by comparing protection by biotic and abiotic particles (ceramic clay) as a function of particle concentration.

\section{MATERIALS AND METHODS}

Particles and seawater. Two types of disinfection experiments were performed: dose experiments with biotic particles, and a particle concentration experiment with biotic and abiotic particles. The planktonic rotifer Brachionus 'Nevada' (size $\sim 250 \mu \mathrm{m}$ ) was used as the biotic particle and was collected from a batch culture (250 l conical vessels in seawater of $20 \%$ salinity at $20^{\circ} \mathrm{C}$ ) with densities between 44 and 394 ind. $\mathrm{ml}^{-1}$. Brachionus 'Nevada' is 1 of 4 distinct phylogenetic lineages within group A of the B. plicatilis species complex as suggested by Gómez et al. (2002). This rotifer can grow in a wide range of salinities and temperatures, and rapid shifts result in only temporary changes in swimming ability (Øie \& Olsen 1993). Mixing of cultures during treatment secured an even distribution of rotifers. Ceramic clay (Vingerling k 148, WBB Fuchs) was used as the abiotic particle. In the disinfection dose experiments, the rotifer culture was diluted (final salinity, 28 to $30 \%$ ) in autoclaved seawater to obtain appropriate densities to examine dose-dependent inactivation of particle-associated and free-living bacteria. In the particle concentration experiment, washed rotifers (biotic) and ceramic clay particles (abiotic) were added to the rotifer culture water ( $45 \mu \mathrm{m}$ filtrate) in increasing amounts and diluted in autoclaved seawater before inactivation of free-living bacteria were compared. The seawater ( $34 \%$ salinity) used in these experiments was collected from Trondhjem Biological Station's high-quality influent water (intake at $70 \mathrm{~m}$ depth), aged (>2 mo in the dark at $\sim 15^{\circ} \mathrm{C}$ ) and autoclaved before use.

Disinfection procedures. Ozonated water was produced by injection of ozone into the experimental mixture through an air stone to a stable ORP of $400 \mathrm{mV}$ controlled by automatic set point with $3 \mathrm{~s}$ delay in a 11 
beaker with continuous stirring. ORP was measured and controlled using Redoxpotential-Steuergerät (Erwin Sander). Ozone was produced by a Sander Ozonisator Ozoniser (2000 $\mathrm{mg} \mathrm{h}^{-1}$; Erwin Sander) supplied with air from an air pump (air pump N022AN.18, KNF Neuberger). Samples were taken by pumping the required volume through a $0.4 \mathrm{~cm}$ (inner diameter) tube using a peristaltic pump into a sterile $50 \mathrm{ml}$ Falcon tube at given time intervals. TRO was measured immediately after each sample withdrawal.

The water subjected to UV treatment was placed in the reaction chamber $(640 \mathrm{ml})$ of a UV water disinfection system (Aquapro 1GPM, 220V/14W, Aquapro Industrial) with continuous stirring. Samples were taken by emptying the reaction chamber into a sterile glass bottle. The average intensity $\left(14.57 \mathrm{~mW} \mathrm{~cm}^{-2}\right)$ at the quartz glass wall was measured by a UVX-25 Radiometer (Ultraviolet Products). The UV dose at the mid-point inside the reaction chamber was calculated based on Beer Lambert's law:

$$
I_{x}=\frac{\varphi}{2 \pi r l} 10^{-A x}
$$

$I_{X}$ is the radiation energy at distance $x$ from the quartz tube $\left(\mathrm{mW} \mathrm{cm}^{-2}\right), \varphi$ is the measured UV output at $254 \mathrm{~nm}$ multiplied by the surface of the quartz glass $(\mathrm{mW}), A$ is the absorbance by the irradiated water, $x$ is the distance from the quartz tube to the mid-point in the chamber, $l$ is the effective length of the UV-arch tube and $r$ is the distance from the lamp centre to the mid-point of the reaction chamber $(\mathrm{cm})$. Absorbance at $254 \mathrm{~nm}$ was measured with a spectrophotometer and the average absorbance in each experiment was used in the calculations. The UV dose was defined as the product of average intensity in the reaction chamber and the exposure time $\left(I_{X} \cdot t\right)$.

Experimental design. In the dose experiments, variable doses for both disinfection methods were achieved by varying the exposure time, and the dose is expressed as $\mathrm{C} \cdot t\left(\mathrm{mg} \mathrm{s}^{-1}\right)$ for ozone and $\mathrm{mJ} \mathrm{cm}^{-2}$ for UV. The particle concentration effect was studied at a UV dose of $586 \mathrm{~mJ} \mathrm{~cm}^{-2}$ and a $\mathrm{C} \cdot t$ value of $30 \mathrm{mg} \mathrm{s} \mathrm{l}^{-1}$ (DPD $0.25 \mathrm{mg} \mathrm{Cl}_{2} \mathrm{l}^{-1}$ ). Biotic particles (0 to $171 \mathrm{mg} \mathrm{DW} \mathrm{l}^{-1}$ rotifers) were collected by filtering the rotifer culture on a $45 \mu \mathrm{m}$ mesh and rinsing the rotifers 5 times in sterile seawater (34\%o salinity). Numbers (rotifers and eggs) were converted to dry weight (DW) biomass, assuming $578 \mathrm{ng}$ DW ind. ${ }^{-1}$ and $228 \mathrm{ng} \mathrm{DW}$ egg $^{-1}$ (Øie et al. 1997). Increasing abiotic particle concentrations (0 to $133 \mathrm{mg} \mathrm{DW}^{-1}$ ceramic clay) were achieved by adding dried ceramic clay $\left(110^{\circ} \mathrm{C}\right.$ for $\left.24 \mathrm{~h}\right)$. The particles were added to culture water, incubated for $15 \mathrm{~min}$ at room temperature, diluted 2-fold in autoclaved seawater to specified densities and exposed to treatment for $2 \mathrm{~min}$. In the dose experiments, samples were taken at time zero (2 samples), and after $0.17,1$, 2, 3, 4, 7, 15 and $30 \mathrm{~min}$ of exposure. In Expt Oz1, the samples were taken after $0.17,1.5,2.5,2.8,3.6,4.1,10$ and $40 \mathrm{~min}$ of exposure.

The release of bacteria from rotifers to the water during the UV and ozone treatments was estimated by adding thoroughly rinsed rotifers to autoclaved seawater prior to disinfection.

Analytical procedures. To determine the number of particle-associated and free-living bacteria, a $50 \mathrm{ml}$ sample of the treated water or of the culture was taken and fractionated in two by filtering through a $45 \mu \mathrm{m}$ mesh. The filtrate represented the free-living bacteria and the concentrated rotifer solution represented the bacteria associated with the rotifers. Culture water of rotifers has been shown to contain little bacterial activity in the size fraction $>1 \mu \mathrm{m}$ (Vadstein et al. 1993), which supports our rationale for classifying the fraction $<45 \mu \mathrm{m}$ as free-living bacteria.

The concentrated rotifers were washed 2 times with a minimum of $50 \mathrm{ml}$ sterile seawater ( $34 \%$ salinity) to remove free-living bacteria. A subsample $(2$ or $3 \mathrm{ml})$ of the washed and concentrated rotifers was homogenised. The filtrate (both experiments) and the homogenised rotifers (only the dose experiments) were serially diluted in sterile seawater (34\% salinity) and spread out on M65-agar plates (0.5 g peptone, tryptone, yeast extract, $15 \mathrm{~g}$ agar, $800 \mathrm{ml}$ aged seawater and $200 \mathrm{ml}$ tap water) to determine the number of colony-forming units (CFU) as an estimate of total numbers of culturable bacteria. CFU was determined after incubation of the agar plates in the dark at $15^{\circ} \mathrm{C}$ for $14 \mathrm{~d}$ by mean of a colony counter (AcoLyte), and expressed as CFU ml ${ }^{-1}$ or CFU rotifer ${ }^{-1}$ for free-living and particle-associated bacteria, respectively. The agar plates were prepared in triplicate, and the average CFU results are presented in this paper. The majority of counted agar plates used for quantification had 20 to $200 \mathrm{CFU} \mathrm{ml}^{-1}$, giving an SD of 4 to $13 \%$ per triplicate. Close to the detection limit, lower numbers of CFU were observed, giving a higher SD as a consequence. A subsample of the washed and concentrated rotifers was fixed in acid Lugol's solution and rotifers were manually quantified with a dissecting microscope.

Chemical and physical variables were determined by withdrawal of an additional sample (30 ml). Measurements of temperature, salinity (salinity refractometer ATC-S/Mill-E, ATAGO), pH (standard meter, PHM210, Radiometer Analytical), absorbance (Ultrospec 2000 UV/Visible spectrophotometer, Pharmacia Biotech) and TRO (ozone treatments) were performed for each sample, including the time zero samples $\left(t_{0}\right)$. In addition, temperature and ORP $(\mathrm{mV})$ were monitored directly in the ozone reaction beaker. TRO were measured by the colorimetric DPD method immedi- 
ately after sample withdrawal using a HACH DR 890 colorimeter. TRO is expressed as $\mathrm{mg} \mathrm{Cl}_{2} \mathrm{l}^{-1}$, and the $\mathrm{C} \cdot t$ value was calculated from the average TRO concentration during the exposure time. The zero samples $\left(t_{0}\right)$ were used as blanks for the DPD measurements and autoclaved filtered seawater was used as a blank for the absorbance measurements.

\section{RESULTS}

\section{Time-zero conditions}

The dose-response relationship for particle-associated and free-living bacteria was studied in 3 separate experiments for the UV treatment and in 4 separate experiments for the ozone treatment. Expts Oz4 and UV4 were performed the same day and with the same culture. This was also done in Expts Oz5 and UV5 and in the particle concentration experiment (ozone and UV). Time-zero conditions and experimental set-ups are presented in Table 1 . The initial $\left(t_{0}\right) \mathrm{CFU}$ of the free-living bacteria ranged from $2.7 \times 10^{6}$ to $2.0 \times$ $10^{7} \mathrm{ml}^{-1}$ in the experiments, corresponding to a $7.4 \times$ variation. The particle-associated $\mathrm{CFU}$ ranged from $5.0 \times 10^{3}$ to $1.12 \times 10^{5} \mathrm{CFU}$ rotifer ${ }^{-1}$ at $t_{0}$, a $22 \times$ variation. If Expt Oz2 is excluded, the range will be reduced to a factor of 6.8 and 3.9 , respectively. The variation in free-living bacteria was partially caused by the variable dilution of the rotifer culture.

\section{Inactivation of bacteria}

In the dose-response experiments, particle-associated bacteria showed a significantly higher survival rate than free-living bacteria in all ozone experiments (Fig. 1). Thus bacteria experienced a high degree of protection when associated with rotifers. The inactivation of free-living bacteria also levelled off at high $C \cdot t$

Table 1. Time zero average counts (CFU) of free-living, particle-associated bacteria and rotifers in the water subjected to ozone or UV treatment

\begin{tabular}{|c|c|c|c|c|}
\hline Expt & $\begin{array}{l}\text { Culture } \\
\text { dilution }\end{array}$ & $\begin{array}{l}\text { Free-living } \\
\left(\mathrm{CFU} \mathrm{ml^{-1 }}\right)\end{array}$ & $\begin{array}{l}\text { Rotifer-associated } \\
\left(\mathrm{CFU} \text { rotifer }^{-1}\right)\end{array}$ & $\begin{array}{c}\text { Rotifers } \\
\mathrm{ml}^{-1}\end{array}$ \\
\hline Oz1 & 2-fold & $6.21 \times 10^{6}$ & $2.86 \times 10^{4}$ & 35 \\
\hline Oz2 & 5 -fold & $1.06 \times 10^{6}$ & $2.04 \times 10^{3}$ & 55 \\
\hline UV3 & 5 -fold & $5.98 \times 10^{6}$ & $1.69 \times 10^{4}$ & 79 \\
\hline Oz4/UV4 ${ }^{\mathrm{a}}$ & 2 -fold & $2.00 \times 10^{7}$ & $9.98 \times 10^{4}$ & 28 \\
\hline Oz5/UV5 ${ }^{\mathrm{a}}$ & 2 -fold & $7.78 \times 10^{6}$ & $1.12 \times 10^{5}$ & 22 \\
\hline Particle conc. Oz/UV ${ }^{a}$ & 2 -fold & $2.96 \times 10^{6}$ & & $\mathrm{~b}$ \\
\hline
\end{tabular}

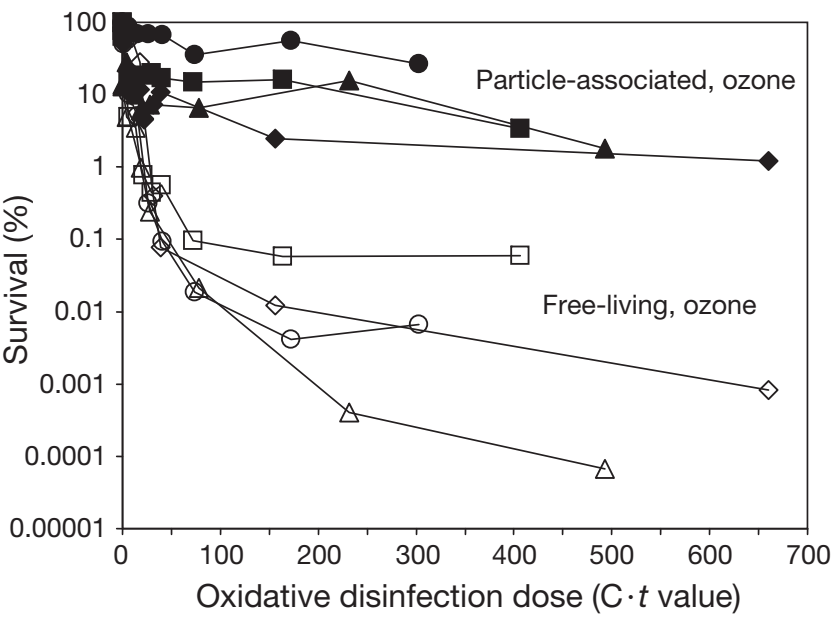

Fig. 1. Survival versus dose response for free-living (open symbols) and particle-associated (solid symbols) bacteria in ozonated rotifer cultures. Expts Oz1 $(\diamond, \diamond)$, Oz2 $(\mathrm{O}, \bullet), \mathrm{Oz} 4$ $(\Delta, \mathbf{\Delta})$ and $\mathrm{Oz} 5(\square, \mathbf{1})$

values, but this can be explained by CFU approaching the detection limit. In general the parallel ozone experiments followed a similar trend; the most deviating $\mathrm{C} \cdot t$ observation in each experiment deviated from the median by a factor $<2$. The only exception was Expts Oz1 and Oz5 at $90 \%$ inactivation of free-living and particle-associated bacteria, respectively (excluded from the kinetics calculations). The average kinetics are presented in Table 2. A $90 \%$ reduction in survival was observed at an average $C \cdot t$ value of 4.1 and $11.5 \mathrm{mg} \mathrm{s} \mathrm{l}^{-1}$ for the free-living and the particle-associated bacteria, respectively. In 3 out of 4 experiments, $99.99 \%$ inactivation of free-living bacteria was obtained at an average $\mathrm{C} \cdot t$ value of $138.2 \mathrm{mg} \mathrm{s} \mathrm{l}^{-1}$, whereas the maximum inactivation was $98 \%$ for the particle-associated bacteria (Fig. 1).

In the UV irradiation experiments, particle-associated bacteria also had higher survival rates than free-living bacteria (Fig. 2). However, the protection due to particle association was much lower than in the ozone experiments, and inactivation levelled off at higher doses for both free-living and particle-associated bacteria, probably due to CFU approaching the detection limit. A $99.9 \%$ reduction in survival of freeliving and particle-associated bacteria was achieved for all the parallel UV experiments at similar doses (the most deviating dose deviated from the median by a factor of 1.3); on average, a dose of $350 \mathrm{~mJ} \mathrm{~cm}^{-2}$ and $2.12 \mathrm{~J} \mathrm{~cm}^{-2}$ was needed, respectively. A $99.99 \%$ inactivation of free-living bacteria was achieved for an average dose of $1.61 \mathrm{~J} \mathrm{~cm}^{-2}$, and 2 out of 3 particleassociated experiments achieved the same 
Table 2. Percentage inactivation by ozonation (4 experiments) and UV irradiation (3 experiments) of free-living and particleassociated bacteria. Data are mean $\pm \mathrm{SD}$. na $=$ not applicable (this level of inactivation was not achieved)

\begin{tabular}{|c|c|c|c|}
\hline $\begin{array}{l}\text { Inactivation } \\
(\%)\end{array}$ & Sample & $\begin{array}{l}\text { Ozone dose } \\
\left(\mathrm{mg} \mathrm{s}^{-1}\right)\end{array}$ & $\begin{array}{l}\text { UV dose } \\
\left(\mathrm{J} \mathrm{cm}^{-2}\right)\end{array}$ \\
\hline 90 & $\begin{array}{l}\text { Free-living } \\
\text { Particle-associated }\end{array}$ & $\begin{array}{r}4.13 \pm 2.37^{\mathrm{a}} \\
11.50 \pm 3.25^{\mathrm{b}}\end{array}$ & $\begin{array}{l}0.05 \pm 0.02 \\
0.11 \pm 0.12\end{array}$ \\
\hline 99 & $\begin{array}{l}\text { Free-living } \\
\text { Particle-associated }\end{array}$ & $\begin{array}{c}21.85 \pm 4.29 \\
\text { na }\end{array}$ & $\begin{array}{l}0.18 \pm 0.04 \\
0.44 \pm 0.38\end{array}$ \\
\hline 99.9 & $\begin{array}{l}\text { Free-living } \\
\text { Particle-associated }\end{array}$ & $\begin{array}{c}48.88 \pm 15.85 \\
\text { na }\end{array}$ & $\begin{array}{l}0.35 \pm 0.03 \\
2.12 \pm 0.44\end{array}$ \\
\hline
\end{tabular}

reduction with approximately $7.55 \mathrm{~J} \mathrm{~cm}^{-2}$ (Fig. 2). A similar dose increase was required to obtain $90 \%$ inactivation of the particle-associated compared to the free-living bacteria for both the UV and ozone experiments. The same was observed for the stepwise (90 to 99 to $99.9 \%$ ) inactivation of the free-living bacteria with both treatments.

The degree of protection of particle-associated bacteria can be expressed as relative percent protection $(\mathrm{RPP}=100 \% \times[1-$ (inactivation of the particleassociated bacteria/inactivation of the free-living bacteria)]). The average RPP in each experiment at elevated doses varied between 5.4 and $46.1 \%$ for the ozone experiments and between 0.05 and $0.2 \%$ for the UV experiments (Fig. 3). If Expt Oz2 is excluded, the ozone experiments are more similar (5.4 to $12.7 \%$ ). On average a 16 -fold increase in dose gave a 5.5 -fold decrease in RPP for the ozone experiments (Expt Oz2 excluded), and for the UV experiments corresponding

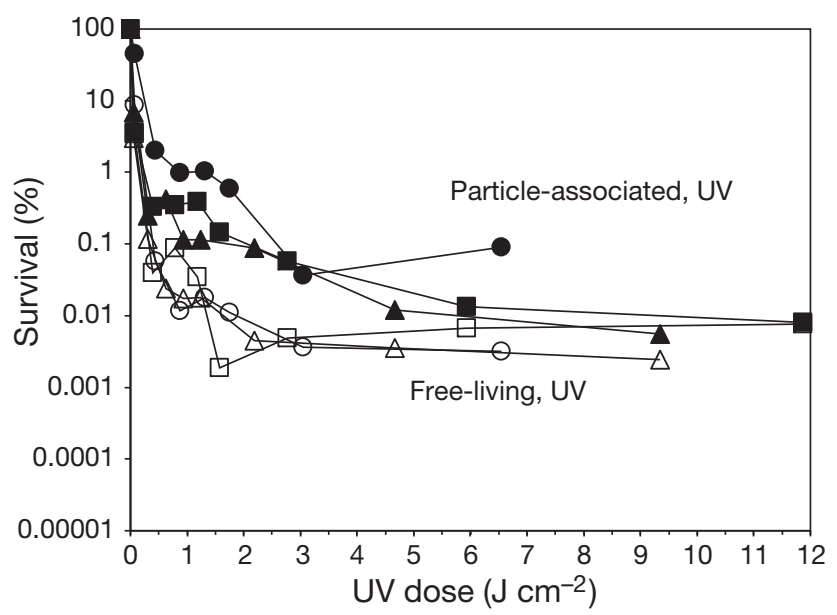

Fig. 2. Survival versus dose response for free-living (open symbols) and particle-associated (solid symbols) bacteria in UV-irradiated rotifer cultures. Expts $\operatorname{UV3}(\mathrm{O}, \bullet), \operatorname{UV4}(\Delta, \boldsymbol{\Delta})$ and UV5 $(\square, \boldsymbol{c})$

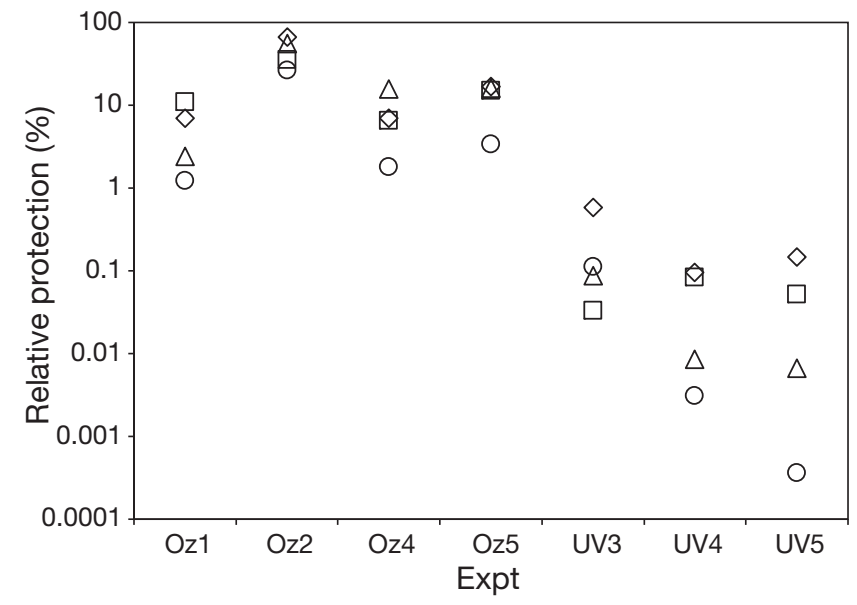

Fig. 3. Relative protection of bacteria by particles in ozoneand UV-treated rotifer culture given as relative percent protection (RPP). Symbols represent treatment time, not doses: $4(\diamond), 7(\square), 15(\Delta)$ and $30 \mathrm{~min}(0) . \mathrm{RPP}=100 \% \times[1-$ (inactivation of the particle-associated bacteria/inactivation of the free-living bacteria)]

numbers are 7.5 -fold increase and 27 -fold decrease. In general each dose step gave a corresponding decrease of RPP in the UV experiments (except Expt UV3), but to a variable degree. This relationship was not evident in the ozone experiments, but the highest dose gave the lowest RPP in each experiment.

The experiment evaluating the effect of concentration of biotic and abiotic particles on survival of freeliving bacteria after UV and ozone treatments is presented in Fig. 4. An effect of particle concentration was observed for both treatments, but with no clear differences between particle types. For the ozone treatment, survival increased from $1.5 \%$ with no particles, to $20 \%$

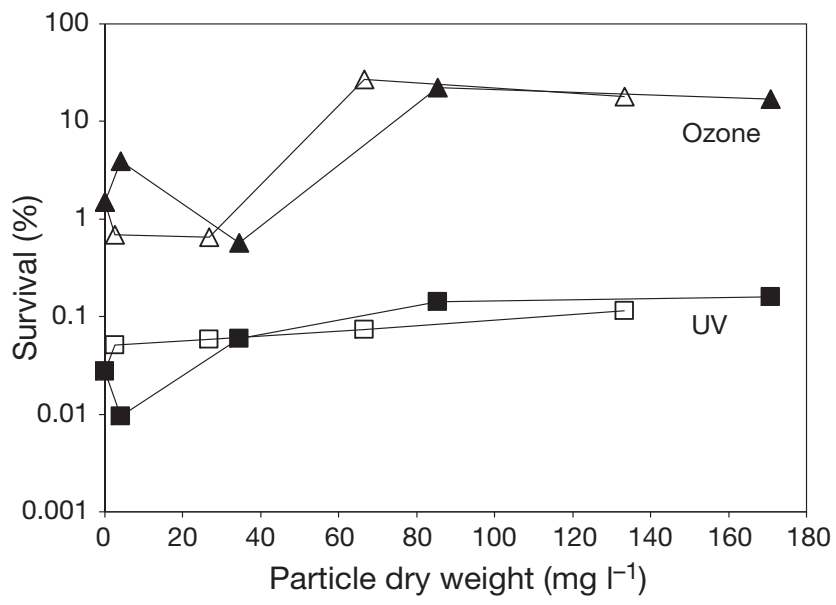

Fig. 4. Effect of biotic (rotifers, solid symbols) and abiotic (ceramic clay, open symbols) particle concentration on survival of bacteria after $\operatorname{UV}(\square, \boldsymbol{\square})$ or ozone $(\boldsymbol{\Lambda}, \Delta)$ treatment. The water was treated for $2 \mathrm{~min}$, giving an average UV dose of $586 \mathrm{~mJ}$ $\mathrm{cm}^{-2}$ and an average $\mathrm{C} \cdot t$ value of $30 \mathrm{mg} \mathrm{s}^{-1}$ 
for particle concentrations above 65 and $85 \mathrm{mg} \mathrm{DW}^{-1}$ for the abiotic and biotic particles, respectively. For the UV treatment, survival increased from $0.03 \%$ with no particles, to $0.1 \%$ for particle concentrations above 110 and $65 \mathrm{mg} \mathrm{DW}^{-1}$ for abiotic and biotic particles, respectively. This corresponds to a $\sim 13$ - and $\sim 3$-fold increase in survival, for the ozone and UV treatment, respectively. For both treatments there was a deviation from the pattern at $4 \mathrm{mg} \mathrm{DW} \mathrm{m}^{-1}$ of biotic particles, but we found no apparent reason for this deviation. The release of bacteria from rotifers to the water during the UV and ozone treatments was low and had an insignificant impact on survival (data not shown). Data presented in Fig. 4 are therefore not corrected for the release of live bacteria from rotifers.

\section{DISCUSSION}

The results obtained demonstrate reduced UV and ozone disinfection efficiency for both particle-associated and free-living bacteria in seawater containing particles. However, the protection was considerably higher for the particle-associated bacteria. Inactivation of free-living bacteria by the 2 disinfection methods responded differently to increased particle concentrations, with no or minor differences between biotic and abiotic particles. Previous studies on disinfection of bacteria in seawater use 2 different approaches, either testing organisms in pure culture (Sugita et al. 1992, Liltved et al. 1995) or heterotrophic communities of bacteria (Liltved \& Cripps 1999, Leonard et al. 2000, Sharrer et al. 2005, Herwig et al. 2006, Perrins et al. 2006a,b, Masters et al. 2008). Reported UV and ozone doses needed to reach a specific inactivation level vary tremendously between these 2 approaches. There may be several reasons for this difference and some will be discussed here. Direct comparison of disinfection doses using these 2 approaches should be avoided, and care should also be taken when comparing results using the same approach because the experimental set-up and bacterial detection methods vary. Inactivation dose data for the free-living bacteria obtained in the present study are in the same range as those published for communities of heterotrophic bacteria. Such studies report larger variation in inactivation doses than the pure culture studies. Reported disinfection doses using the community approach and our results are significantly higher than the doses recommended in aquaculture (Wedemeyer 1996, Liltved 2002). Earlier studies (Liltved \& Cripps 1999, Wu et al. 2005) of particle effects on UV-irradiated water also demonstrate protection of bacteria, but little is known about the effects of increased disinfection dose (UV or ozone), particle concentration, and particle type on the inactivation of heterotrophic bacteria in seawater. Based on our data, it is possible to elaborate on the differences in inactivation of free-living and particle (biotic and abiotic)associated bacteria by UV irradiation and ozonation of seawater.

The difference observed in CFU for both free-living and particle-associated bacteria at $t_{0}$, especially in Expt Oz2, may be related to the variable status of the rotifer cultures. It has been shown that densities of rotifer-associated and free-living bacteria vary considerably depending on total grazing pressure, defecation and feeding regime (Skjermo \& Vadstein 1993, Vadstein et al. 1993, O. Vadstein unpubl.).

The dose-response results demonstrated a significantly higher survival rate of bacteria associated with rotifers. For both methods, a 2-stage inactivation was observed, which is a deviation from first-order kinetics (Figs. 1 \& 2). Inactivation of particle-associated bacteria in the ozone experiments was less affected by increased dose than the UV experiments. The low initial TRO concentration (ORP) or insufficient contact time can also contribute to the slow inactivation (Sugita et al. 1992, Perrins et al. 2006a,b), possibly making the $\mathrm{C} \cdot t$ value insufficient to describe dose. Liltved et al. $(1995,2006)$ showed inactivation curves of fish pathogenic bacteria and viruses in seawater exposed to UV irradiation and ozonation close to and deviating from first-order kinetics, respectively. The inactivation curves levelled off at higher survival for the particle-associated than for the free-living bacteria. This can be explained by either protection of the bacteria in the digestive tract of the rotifer or the presence of populations with higher disinfection tolerance associated with rotifers. Comparative studies of the bacterial flora in water and associated with rotifers showed strong correlation (Skjermo \& Vadstein 1993), making the presence of bacteria with higher tolerance associated to rotifers less likely. Protection by particles expressed as RPP indicates different protection at elevated doses for the 2 disinfection methods (Fig. 3). The dose increase had a greater effect on RPP for the UVtreated than for the ozone-treated bacteria, indicating a TRO threshold level for the ozone dose. This may be different at higher ORP (initial TRO concentrations). The higher survival rates of UV- and ozone-exposed bacteria associated with rotifers, even at very high disinfection doses, indicates mechanisms to escape disinfection.

Protection of bacteria in the shadow of other particles seems likely for UV irradiation (Liltved \& Cripps 1999), but should be absent with ozonation, where consumption or a rate-limited transport of disinfectants into the aggregates may be the protection mechanism. We hypothesised that biotic particles would give better protection than abiotic particles for both treatments, 
with larger differences between the biotic and abiotic particles for the UV treatment than for the ozone treatment. Effects like shielding, absorption and scattering in the UV experiment was believed to reduce the UV treatment efficiency more than the consumption and rate-limited transport of disinfectants in the ozone treatment. Our results from the particle concentration experiment demonstrated increased survival with increasing particle concentration for both particle types and disinfection methods, but with a more pronounced protection for the ozone treatment and little difference between the biotic and abiotic particles (Fig. 4). The increased survival with increasing particle concentration of ozone-treated bacteria (13-fold at maximum particle concentration) is believed to be caused mainly by the inactivation of disinfectants by the particles before bacteria. Thus, increased survival can also partly be attributed to the low TRO concentration $\left(0.25 \mathrm{mg} \mathrm{s}^{-1}\right)$ and insufficient contact time. Both types of particles exhibited little protection (3-fold at maximum particle concentration) during UV irradiation of bacteria, indicating weaker protective properties against UV irradiation. The inactivation of disinfectants by particles in the ozone experiment seems to protect the bacteria better than the shading by particles in the UV experiment. The efficiency of UV and ozone treatment may also be affected by the contact time between particles and bacteria prior to treatment (Wu et al. 2005), but is believed to be of minor importance in our experimental conditions and for the free-living bacteria. Increased particle concentration was not clearly detected with UV absorbance measurements, but increased protection was observed. Particles in water may have different absorbance and scattering properties, influencing measurements of UV absorbance and determination of the fluence rate. Some particles may increase the fluence rate and others like clay and organic matter may reduce the fluence rate (Mamane et al. 2006). This may influence conventional measurements of suspended particles; therefore measurements of scattering should be incorporated in order to more accurately reflect absorbance in UV disinfection systems.

Lasting inactivation of bacteria may be impossible to achieve, and one has to consider the time span for which the disinfection effect should last. Further work on recolonisation kinetics of disinfected water by heterotrophic bacteria should be performed to gain further knowledge on the long-term effects of disinfection. For treatment of e.g. ballast water and effluents from landbased fish farming, particle properties and concentrations should be evaluated to set a sufficient disinfection dose and/or in combination with particle removal. This will improve the overall bacterial inactivation efficiency and reduce the risk of introducing alien species and possible spreading of pathogenic bacteria.

\section{CONCLUSIONS}

This study examined the protective mechanisms provided by biotic and abiotic particles during UV and ozone inactivation of heterotrophic bacteria in seawater. Our results support the hypothesis that bacteria embedded in or attached to particles are protected, and only partially support the hypothesis that disinfection efficiency of free-living bacteria is negatively correlated to particle concentration. There was little difference in protection between the particle types. However, the biotic particles protected bacteria slightly better during UV treatment, and increasing particle concentration reduced the ozone disinfection efficiency more than the UV disinfection efficiency. Thus the hypothesis that biotic particles give higher protection than abiotic particles is supported by the UV experiment, but not the ozone experiment. Our results do not support the hypothesis that disinfection by UV is more affected by particle concentration than ozone disinfection. The ozone experiments show a large difference in inactivation of free-living versus particle-associated bacteria and demonstrate particle protection of freeliving bacteria. The UV experiments show less difference in inactivation of free-living versus particleassociated bacteria and little particle protection of free-living bacteria. The overall results confirm differing protection kinetics and mechanisms for heterotrophic bacteria for the 2 disinfection methods used.

Acknowledgements. This study is a part of a $\mathrm{PhD}$ study funded by VISTA, Statoil's basic research programme which is conducted in close collaboration with the Norwegian Academy of Science and Letters. The authors thank the Masters student J. Fincke for assistance in performing the experiments.

\section{LITERATURE CITED}

Buchan KAH, Martin-Robichaud DJ, Benfey TJ (2005) Measurement of dissolved ozone in seawater: a comparison of methods. Aquacult Eng 33:225-231

Gómez A, Serra M, Carvalho GR, Lunt DH (2002) Speciation in ancient cryptic species complexes: evidence from the molecular phylogeny of Brachionus plicatilis (Rotifera). Evolution 56:1431-1444

> Herwig RP, Cordell JR, Perrins JC, Dinnel PA and others (2006) Ozone treatment of ballast water on the oil tanker S/T Tonsina: chemistry, biology and toxicity. Mar Ecol Prog Ser 324:37-55

> Leonard N, Guiraud JP, Blancheton JP (2000) Populations of heterotrophic bacteria in an experimental recirculating aquaculture system. Aquacult Eng 22:109-120

Liltved H (2002) Ozonation and UV-irradiation. In: Timmons MB, Ebeling JM, Wheaton FW, Summerfelt ST, Vinci BJ (eds) Recirculating aquaculture systems, 2nd edn. Cayuga Aqua Ventures, Ithaca, NY, p 393-424

Liltved H, Cripps SJ (1999) Removal of particle-associated bacteria by prefiltration and ultraviolet irradiation. Aquacult 
Res 30:445-450

Liltved H, Landfald B (1996) Influence of liquid holding recovery and photoreactivation on survival of ultravioletirradiated fish pathogenic bacteria. Water Res 30:1109-1114

Liltved H, Hektoen H, Efraimsen H (1995) Inactivation of bacterial and viral fish pathogens by ozonation or UV irradiation in water of different salinity. Aquacult Eng 14:107-122

Liltved H, Vogelsang C, Modahl I, Dannevig BH (2006) High resistance of fish pathogenic viruses to UV irradiation and ozonated seawater. Aquacult Eng 34:72-82

Mamane H, Ducoste JJ, Linden KG (2006) Effect of particles on ultraviolet light penetration in natural and engineered systems. Appl Opt 45:1844-1856

Masters AL, Vinci BJ, Brazil B, Creaser DA, Summerfelt ST (2008) Performance characterization of influent and effluent treatment systems: a case study at Craig Brook National Fish Hatchery. Aquacult Eng 38:66-76

Øie G, Olsen Y (1993) Influence of rapid changes in salinity and temperature on the mobility of the rotifer Brachionus plicatilis. Hydrobiologia 255-256:81-86

Øie G, Reitan KI, Olsen Y (1997) Comparison of rotifer culture quality with yeast plus oil and algal-based cultivation diets. Aquacult Int 2:225-238

Perrins JC, Cooper WJ, van Leeuwen J, Herwig RP (2006a) Ozonation of seawater from different locations: formation and decay of total residual oxidant-implications for ballast water treatment. Mar Pollut Bull 52:1023-1033

Editorial responsibility: Hans Heinrich Janssen, Oldendorf/Luhe, Germany
Perrins JC, Cordell JR, Ferm NC, Grocock JL, Herwig RP (2006b) Mesocosm experiments for evaluating the biological efficacy of ozone treatment of marine ballast water. Mar Pollut Bull 52:1756-1767

Sharrer MJ, Summerfelt ST, Bullock GL, Gleason LE, Taeuber J (2005) Inactivation of bacteria using ultraviolet irradiation in a recirculating salmonid culture system. Aquacult Eng 33:135-149

Skjermo J, Vadstein O (1993) Characterization of the bacterial flora of mass cultivated Brachionus plicatilis. Hydrobiologia 255-256:185-191

Sugita H, Asai T, Hayashi K, Mitsuya T, Amanuma K, Maruyama C, Deguchi Y (1992) Application of ozone disinfection to remove Enterococcus seriolicida, Pasteurella piscicida, and Vibrio anguillarum from seawater. Appl Environ Microbiol 58:4072-4075

Tango MS, Gagnon GA (2003) Impact of ozonation on water quality in marine recirculation systems. Aquacult Eng 29: 125-137

> Vadstein O, Øie G, Olsen Y (1993) Particle size dependent feeding by the rotifer Brachionus plicatilis. Hydrobiologia 255-256:261-267

Wedemeyer GA (1996) Physiology of fish in intensive culture. International Thompson Publishing, New York, NY

- Wu Y, Clevenger T, Deng B (2005) Impacts of goethite particles on UV disinfection of drinking water. Appl Environ Microbiol 71:4140-4143

Submitted: September 10, 2008; Accepted: October 21, 2008 Proofs received from author(s): November 17, 2008 